\title{
Compound Heterozygous Sickle Cell- $\beta$-Thalassemia: A Case Report from Upper Assam, India
}

\author{
ANJU BARHAI TELI, RUMI DEORI, SIDHARTHA PROTIM SAIKIA, BIPUL CH. KALITA
}

\section{ABSTRACT}

Sickle cell- $\beta$-thalassemia $[\mathrm{Hb} S / \beta$ - thalassemia] is a rare type of hemoglobinopathy. The clinical characteristics of $\mathrm{Hb} \mathrm{S} / \beta$ - thalassemia are highly variable from a completely asymptomatic state to a severe disorder like homozygous sickle cell disease. In India IVS I-5 $(\mathrm{G} \rightarrow \mathrm{C})$ is the most common $\beta$-thalassemia allele. In this study we presented a case of compound heterozygous $\mathrm{Hb} S / \beta$ - thalassemia in a 14-year-old female with complaints of anemia with weakness, joint pain and splenomegaly. The patient and her parents were diagnosed by HPLC and for detection of mutational pattern of $\beta$-thalassemia; ARMS-PCR and DNA sequencing were performed. The HPLC report suggested that the patient have $\mathrm{Hb} \mathrm{S} / \beta$ - thalassemia and molecular diagnosis confirmed that the patient inherited IVS I-5 $(\mathrm{G} \rightarrow \mathrm{C}) \beta$ - thalassemia mutation.

Keywords: Anemia, ARMS-PCR, DNA sequencing, HPLC

\section{CASE REPORT}

A 14-year-old female with complaints of anemia with weakness, joint pain and stomach pain presented in the Outpatient Department of Pediatrics. After taking informed consent systemic examination of the patient was done and the patient's spleen was found to be enlarged.

Blood samples of the patient and her parents were collected in EDTA vials after obtaining informed consent. Hematological data of the blood samples were determined on an automated blood cell counter (SYSMEX XS-800i, Japan) and the hemoglobin typing was performed by high performance liquid chromatography (HPLC) using the BIORAD D10 Hemoglobin Testing System. The hematological analysis showed that the patient was anemic [Table/Fig-1]. The hemoglobin typing results [Table/Fig-2] revealed that the patient was compound heterozygous for $\mathrm{Hb} S / \beta$ - thalassemia, the father had $\beta$ thalassemia trait and the mother had sickle cell trait.

Molecular analysis was done to identify $\beta$ - thalassemia mutation pattern associated with the patient. Genomic DNA was extracted by using QIAamp® DNA Blood Mini Kit (QIAGEN, Germany) for doing amplification refractory mutation system polymerase chain reaction (ARMS-PCR). ARMS-PCR was done following standard protocol [1]. Amplification was carried out in a $50 \mu \mathrm{l}$ reaction mixture

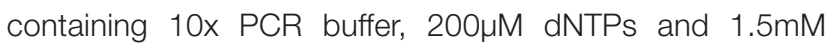
$\mathrm{MgCl}_{2}$. All the required primers, $2 \mu \mathrm{l}$ of DNA sample, $0.5 \mathrm{U}$ of National Journal of Laboratory Medicine. 2016 Apr, Vol 5(2): 63-65
GoTaq ${ }^{\circledR}$ Flexi DNA Polymerase and nuclease free water were added to the reaction mixture. Amplification was carried out in an Arktik ${ }^{\mathrm{TM}}$ Thermal Cycler (Thermo Scientific, USA) as following sequence: $94^{\circ} \mathrm{C}$ for 5 minutes followed by 30 cycles of $94^{\circ} \mathrm{C}$ for 45 second, $65^{\circ} \mathrm{C}$ for 45 seconds and $72^{\circ} \mathrm{C}$ for 1.5 minutes, with a final extension at $72^{\circ} \mathrm{C}$ for 7 minutes. Then $15 \mu \mathrm{l}$ aliquot of the PCR product was separated on a $1.5 \%$ agarose gel in $1 \times$ Tris-borat-EDTA (TBE) buffer. The gel was stained with ethidium bromide and visualized under gel documentation system for the result. ARMS-PCR revealed that the $\beta$ - thalassemia mutation pattern inherited by the patient was IVS I-5 $(\mathrm{G} \rightarrow \mathrm{C})$ mutation [Table/Fig-3]. The same mutation pattern was also found in the patient's father [Table/Fig-3]. Finally the PCR products were sequenced by automated DNA sequencer based on Sanger method to confirm the IVS I-5 $(\mathrm{G} \rightarrow \mathrm{C})$ mutation [Table/Fig-4].

\begin{tabular}{|l|c|c|c|}
\hline $\begin{array}{l}\text { Hematological } \\
\text { Parameters }\end{array}$ & Patient & Father & Mother \\
\hline $\mathrm{Hb}(\mathrm{g} / \mathrm{dl})$ & 5.9 & 12.0 & 12.2 \\
\hline $\mathrm{MCV}(\mathrm{fL})$ & 75.00 & 69.90 & 88.50 \\
\hline $\mathrm{MCH}(\mathrm{pg})$ & 23.00 & 22.60 & 29.10 \\
\hline $\mathrm{MCHC}(\mathrm{g} / \mathrm{dl})$ & 30.7 & 32.3 & 32.9 \\
\hline $\mathrm{RBC} \times 10^{6} / \mu \mathrm{l}$ & 2.56 & 5.31 & 4.19 \\
\hline
\end{tabular}

[Table/Fig-1]: Showing hematological parameters of patient and parents. 


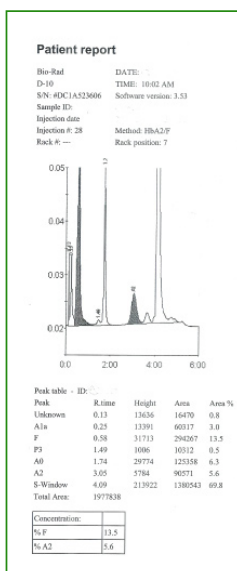

A

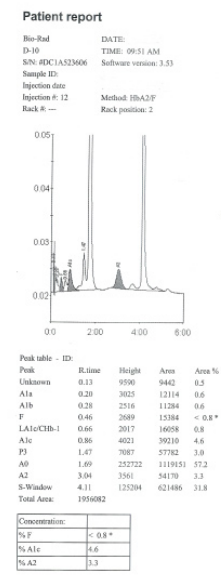

B

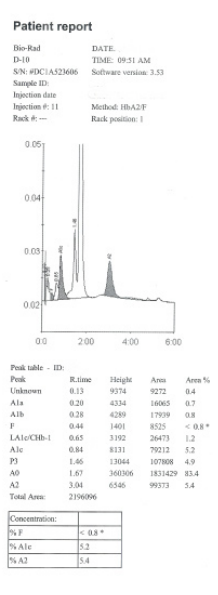

$\mathrm{C}$
[Table/Fig-2]: Showing hemoglobin typing result of the patient (A), patient's mother (B) and patient's father (C).

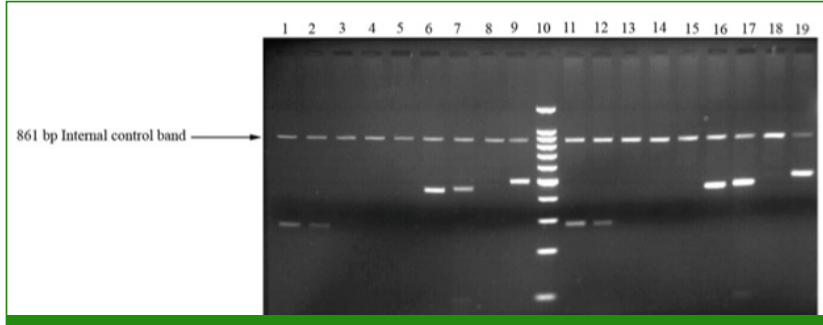

[Table/Fig-3]: Showing IVS I-5 (G $\rightarrow$ C) mutation. Lane 1: Father: IVS I-5 (G $\rightarrow$ C)M , Lane 2: Father: IVS I-5 $(\mathrm{G} \rightarrow \mathrm{C}) \mathrm{N}$, Lane 6: Father: Fr 41/42N, Lane 7: Father: IVS 1-1N, Lane 9: Father: Codon 15N, LANE 10: 100bp DNA ladder, Lane 11: Patient: IVS I-5 (G $\rightarrow$ C)M, Lane 12: Patient: IVS I-5 (G $\rightarrow \mathrm{C}) \mathrm{N}$, Lane 16: Patient: Fr 41/42N, Lane 17: Patient: IVS 1-1N, LANE 19: Patient: Codon 15N.
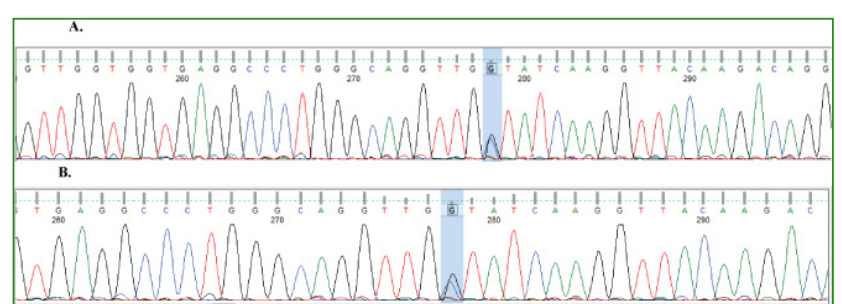

[Table/Fig-4]: Showing the sequences of IVS I-5 $(\mathrm{G} \rightarrow \mathrm{C})$ mutation of the patient $(A)$ and patient's father $(B)$.

After complete diagnosis; folic acid course and 2 units of blood transfusion had been given to the patient. Follow-up of the patient had been done after confirmation of diagnosis along with genetic counseling.

\section{DISCUSSION}

Thalassemia and sickle cell disease have impacting on the population of low income countries [2]. The combination of the sickle cell mutation and $\beta$-thalassemia mutation results $\mathrm{Hb} \mathrm{S} / \beta$ - thalassemia. In India 52 mutations accounted for $97.5 \%$ of all $\beta$-thalassemia alleles and IVS I-5 $(\mathrm{G} \rightarrow \mathrm{C})$ is the most common disease allele (54.7\%) [3]. The prevalence of IVS I-5 $(\mathrm{G} \rightarrow \mathrm{C})$ is $44.8 \%$ in the North and $71.4 \%$ in the East India [3].

$\mathrm{Hb} S / \beta$ - thalassemia disease is a hemoglobinopathy. Clinically, the disorder causes symptoms of moderate anemia and signs of sickle cell anemia. The incidence of $\beta$ - thalassemia trait and sickle cell hemoglobinopathy in India varies between $3-17 \%$ and $1-44 \%$ respectively $[4,5]$. $\beta$ - thalassemia is characterized by its genetic heterogeneity at the molecular level and more than 300 mutations of the $\beta$ - globin gene have been characterized all over the world [6]. There are few $\beta$-thalassemia mutations which are common in India. Six mutations, codon 8-9 (+G), codon $15(\mathrm{G} \rightarrow \mathrm{A})$, codon 41/42 (-TCTT), IVS 1-1 $(\mathrm{G} \rightarrow \mathrm{T})$, IVS I-5 $(\mathrm{G} \rightarrow \mathrm{C})$ and $619 \mathrm{bp}$ deletion at 3 ' end of $\beta$-globin gene, account for about $80 \%$ of $\beta$-thalassemia mutation in Indian population [7].

Thalassemia and Sickle cell disease are two major erythrocytic genetic disorders prevalent in India. $\beta$ Thalassemia is predominantly found in the Mediterranean countries, the Middle East, Central Asia, India, North Coast of Africa and South America [8]. The prevalence of the sickle gene in India is found to vary from 2-34\% [9]. The average frequency of Sickle cell disorders in India is $4.3 \%$ [10]. Sickle cell hemoglobin is mainly prevalent among the Tea garden communities of Assam [11]. The association of $\beta$ - thalassemia with sickle cell hemoglobin is rare, which was reported as 1.7\% [12].

For diagnosis of $\mathrm{Hb} \mathrm{S} / \beta$-thalassemia; hemoglobin typing by HPLC is very important. Elevated $\mathrm{HbA} 2$ is the most significant parameter in the identification of $\beta$-thalassemia carriers and the result should be interpreted together with other hematological and biochemical parameters [13]. HPLC is a method that allows rapid and precise detection of $\mathrm{Hb}$ variants, as well as sensitive quantitation of $\mathrm{HbA} 2$ [14]. When $\mathrm{Hb} \mathrm{S}$ variant is present, percentage of $\mathrm{Hb} \mathrm{A} 2$ and $\mathrm{Hb}$ $F$, family history, clinical data and hematological parameters help for distinguishing between homozygosis for $\mathrm{Hb} S$ and $\mathrm{Hb} \mathrm{S} / \beta$ - thalassemia [15-18].

In the present study, ARMS-PCR and automated DNA sequencer has been used for detection of $\beta$-thalassemia mutations. ARMS-PCR has the advantage that it is theoretically possible to detect any known mutation [19].

When considering the findings associated with $\mathrm{Hb} \mathrm{S} / \beta$ thalassemia, blood transfusion might be the best treatment; however, many more $\mathrm{Hb} \mathrm{S} / \beta$ - thalassemia case findings are necessary to more clearly identify an optimal treatment strategy. 


\section{CONCLUSION}

Present study shows that the molecular techniques are very important for diagnosis of $\mathrm{Hb} S / \beta$-thalassemia. Correct diagnosis of $\mathrm{Hb} \mathrm{S} / \beta$-thalassemia can be made based on high performance liquid chromatography (HPLC) testing, ARMS-PCR and DNA sequencing.

\section{REFERENCES}

[1] Bhardwaj U, Zhang HY, Lorey F, Linda ML, Edward MRB. Molecular Genetic confirmatory testing from new born screening samples for the common African-American, Asian Indian, Southeast Asian and Chinese $\beta$-thalassaemia mutations. Am J Hematol. 2005; 78: 249-55.

[2] WHO Guidelines for the control of hemoglobin disorders: report of the $\mathrm{VI}^{\text {th }}$ annual meeting of the WHO working group on haemoglobinopathies, Cagliari, Sardinia, 8-9 April, 1989. Geneva, World Health Organization (unpublished document WHO/HDP/WG/HA/89.2).

[3] Black ML, Sinha S, Agarwal S, Colah R, Das R et al. A descriptive profile of $\beta$-thalassaemia mutations in India, Pakistan and Sri Lanka. J Community Genet. 2010; 1:149-57.

[4] Balgir RS. The burden of hemoglobinopathies in India and the challenges ahead. Curr Sci. 2000; 79:1536-47.

[5] Balgir RS. The genetic burden of hemoglobinopathies with special reference to community health in India and the challenges ahead. Indian J Hemat Blood Transfus. 2002; 20:02-07.

[6] Satpute SB, Bankar MP, Momin AA. The Prevalence of $\beta$ -Thalassemia Mutations in South Western Maharashtra. Ind $J$ Clin Biochem. 2012; 27:389-93.

[7] Jain V, Sachdev A, Lokeshwar MR. Prevention of thalassemia. In: Sachdeva A, Lokeshwar MR, Shah N, Agarwal BR editors. Hemoglobinopathies. New Delhi: Jaypee Brothers Publishers, 2006; 94-104.

[8] Gallanello R, Origa R. Beta-thalassaemia. Orphanet J of Rare diseases. 2010; 5:11.
[9] Mohanty D, Mukherjee M. Sickle cell disease in India. Curr Opin Hematol. 2002; 9:117-22.

[10] Balgir RS. Epidemiology, Population health genetics and phenotypic diversity of Sickle cell disease in India. IJBA. 2007; 1(2).

[11] Balgir RS, Sharma SK. Distribution of sickle cell haemoglobin in India. Indian J Hematol Blood Transfus. 1988; 6:1-14.

[12] Balgir RS. Spectrum of hemoglobinopathies in the state of Orissa, India: A ten years cohort study. JAPI . 2005; 53:102126.

[13] Mosca A, Paleari R, Ivaldi G, Galanello R, Giordano PC. The role of haemoglobin A2 testing in the diagnosis of thalassaemias and related haemoglobinopathies. J Clin Pathol. 2009; 62:13-21.

[14] Greene DN, Pyle Al, Chang JS, Hoke C, Lorey T. Comparison of Sebia capillarys flex capillary electrophoresis with the BioRad Variant II high pressure liquid chromatography in the evaluation of hemogloginopathies. Clin Chim Acta. 2012; 413(15-16):1284-90.

[15] Giordano PC. Strategies for basic laboratory diagnostics of the haemoglobinopathies in multi-ethnic societies: interpretation of results and pitfalls. Inter J of Lab Haematology. 2013; 35: 465-79.

[16] Head CE, Conroy M, Jarvis M, Phelan L, Bain BJ. Some observations on the measurement of haemoglobin $A 2$ and $S$ percentages by high performance liquid chromatography in the presence and absence of $\alpha$-thalassemia. J Clin Pathol. 2004; 57(3): 276-80.

[17] Clarke GM, Higgins TN. Laboratory investigation for hemoglobinopathies and thalassemias: review and update. Clin Chem. 2000; 46 (8): 1284-90.

[18] Steinberg $\mathrm{MH}$, Compound heterozygous and other sickle hemoglobinopathies. In: Steinberg MH, Forget BG, Higgs DR, Nagel RL, editor. Disorders of hemoglobin: genetics, pathophysiology and clinical management. $1^{\text {st }}$ ed. Cambridge, UK: Cambridge University Press; 2001.p. 786-810.

[19] Newton CR, Graham A, Heptinstall LE, Powell SJ, Summers C, Kalsheker $\mathrm{N}$ et al. Analysis of any point mutation in DNA. The amplification refractory mutation system (ARMS). Nucleic Acids Res. 1989; 17: 2503-16.

\section{AUTHOR(S):}

1. Dr. Anju Barhai Teli

2. Dr. Rumi Deori

3. Mr. Sidhartha Protim Saikia

4. Dr. Bipul Ch. Kalita

\section{PARTICULARS OF CONTRIBUTORS:}

1. Associate Professor, Department of Biochemistry, Assam Medical College \& Hospital, Dibrugarh, Assam, India.

2. Assistant Professor, Department of Biochemistry, Assam Medical College \& Hospital, Dibrugarh, Assam, India.

3. Senior Research Fellow, Department of Anatomy, Assam Medical College \& Hospital, Dibrugarh, Assam, India.
4. Associate Professor, Department of Medicine, Assam Medical College \& Hospital, Dibrugarh, Assam, India.

\section{NAME, ADDRESS, E-MAIL ID OF THE CORRESPONDING AUTHOR:}

Mr. Sidhartha Protim Saikia,

Department of Anatomy, Assam Medical College \& Hospital,

Dibrugarh-786002, Assam, India.

E-mail: sidharth_saikia@hotmail.com

\section{FINANCIAL OR OTHER COMPETING INTERESTS:} None. 